\title{
Assessment of heavy metal toxicity in four species of freshwater ciliates (Spirotrichea: Ciliophora) from Delhi, India
}

\author{
Jeeva Susan Abraham ${ }^{1}$, S. Sripoorna ${ }^{1}$, Ashish Choudhary ${ }^{1}$, Ravi Toteja ${ }^{1}$, \\ Renu Gupta ${ }^{2}$, Seema Makhija ${ }^{1, *}$ and Alan Warren ${ }^{3}$ \\ ${ }^{1}$ Acharya Narendra Dev College, University of Delhi, Delhi 110 019, India \\ ${ }^{2}$ Maitreyi College, University of Delhi, Delhi 110021 , India \\ ${ }^{3}$ Department of Life Sciences, Natural History Museum, London, SW7 5BD, UK
}

In vitro laboratory experiments were conducted to determine the toxicity (per cent survival and $\mathrm{LC}_{50}$ ) of essential and non-essential heavy metals (cadmium, copper, nickel, lead and zinc) in four spirotrich ciliates: Euplotes sp., Notohymena sp., Pseudourostyla sp. and Tetmemena sp. isolated from three different freshwater ecosystems in the Delhi region, India. The toxicity of the heavy metals was found to vary among the different ciliates. Copper was most toxic (24 h$\mathrm{LC}_{50}$ value ranged between 0.125 and $0.74 \mathrm{mg} / \mathrm{l}$ ) and zinc was least toxic ( $24 \mathrm{~h} \mathrm{LC}_{50}$ value ranged between 46.98 and $144.32 \mathrm{mg} / \mathrm{l})$ to each of the ciliates. Of the four ciliates, Notohymena sp. had the highest tolerance limit to three heavy metals $(\mathrm{Cu}, \mathrm{Cd}$ and $\mathrm{Pb}$ ) out of the five tested. This study shows the high potentiality of using freshwater ciliates for monitoring the intensity and potency of ecological damage caused by heavy metals in aquatic ecosystems.

Keywords: Ciliates, freshwater, heavy metals, toxicity.

THERE is a global increase in the concentration of heavy metals in the environment mainly due to anthropogenic activities and India is no exception to this ${ }^{1}$. Although some heavy metals are essential micronutrients, all may be toxic if present in sufficiently high concentration in a bioavailable form, mainly as a result of metabolic interference and mutagenesis. The presence of heavy metals in aquatic environments is a major concern because of their threat to plant and animal life, thus disturbing the natural ecological balance ${ }^{2}$. Many freshwater ecosystems, including lakes, ponds, rivers and reservoirs are exposed to heavy metal contamination from a range of sources, primarily wastewater discharges from industry and households $^{3,4}$. Most of the heavy metals have a long half-life and cannot be degraded, but may instead bio-accumulate throughout the food chain leading to physiological stress causing ecological disturbance ${ }^{5-7}$.

*For correspondence. (e-mail: seemamakhija@andc.du.ac.in)
Toxicity of various heavy metals can be studied using ciliated protists $^{8-10}$. These eukaryotic microorganisms are found in a variety of trophic niches, have generation time of 3-7 h and many are easy to culture in vitro ${ }^{11}$. Ciliates share a higher degree of functional and genetic similarities with humans than bacteria or yeast (microbial eukaryotic model organism $)^{12-14}$. All these properties make them suitable candidates both for eco-toxicological studies and for monitoring water quality ${ }^{15-17}$.

In the present study, we assess the toxicity of essential $(\mathrm{Cu}$ and $\mathrm{Zn})$ and non-essential $(\mathrm{Cd}, \mathrm{Ni}$ and $\mathrm{Pb})$ heavy metals on ciliated protists isolated from three different freshwater ecosystems (river, lake and pond) in the Delhi region, India. The diversity of free-living ciliates in the study sites was observed for a period of one year. The most frequently encountered ciliate species were from four genera, namely Euplotes, Notohymena, Pseudourostyla and Tetmemena (Figure 1) and all were easily cultured under laboratory conditions. Toxicity assays were carried out in vitro in order to determine the sensitivity and survival of Euplotes sp., Notohymena sp., Pseudourostyla sp. and Tetmemena sp. to different doses of heavy metals.

\section{Materials and methods}

\section{Study area}

Delhi is located in northern India. It is bordered by the states of Haryana to the north, west and south, and Uttar Pradesh (UP) to the east. Prominent features of the geography of Delhi include the floodplains of River Yamuna. In the present study three sites were selected in different ecological regions of Delhi.

Site I: Okhla Bird Sanctuary (28.5700 $\left.{ }^{\circ} \mathrm{N}, 77.3023^{\circ} \mathrm{E}\right)$ : This is a bird sanctuary at the Okhla Barrage over the Yamuna. The site is located at the point where the river exits Delhi and enters UP. The most prominent feature of the sanctuary is the large lake created by a dam over the 


\section{RESEARCH ARTICLES}
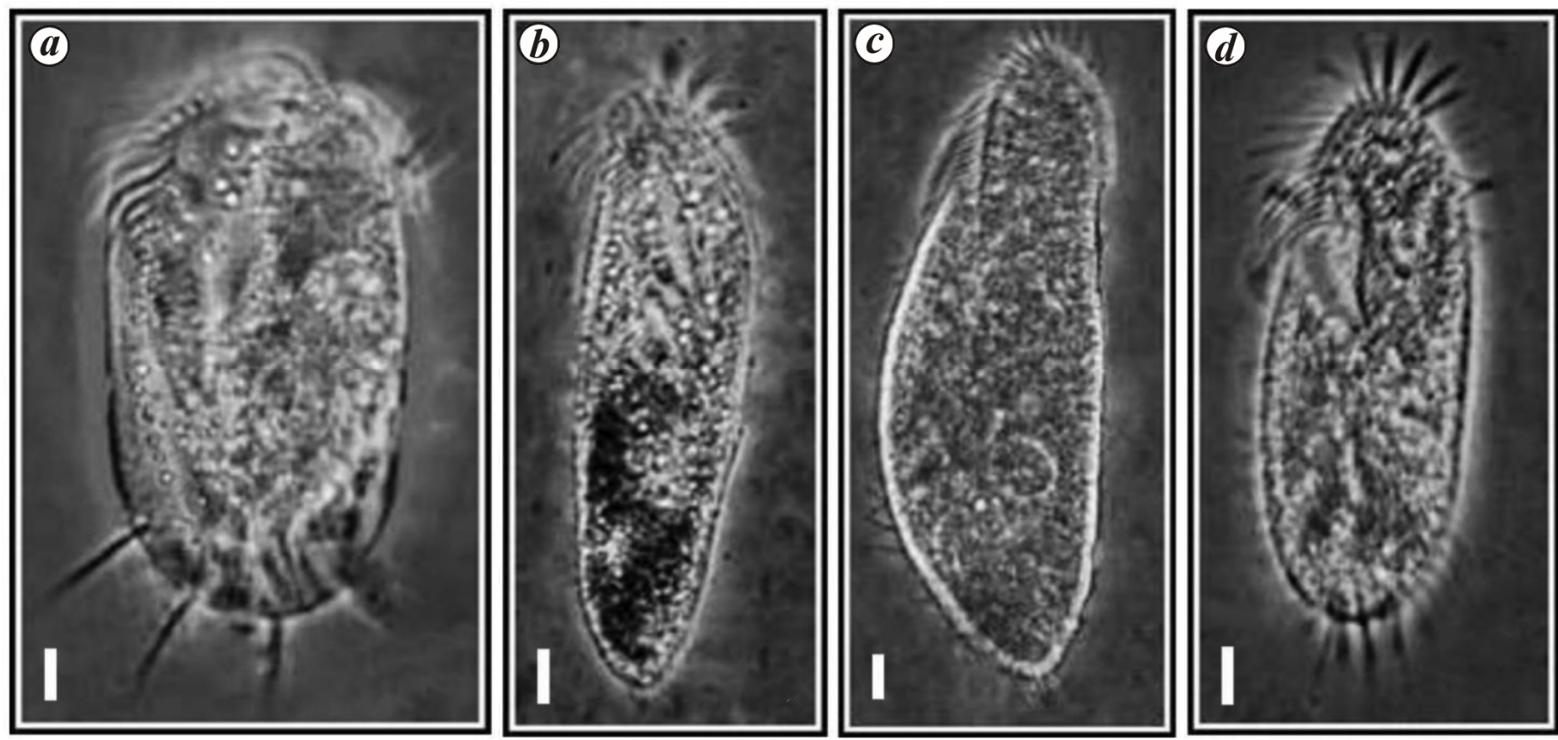

Figure 1. Phase contrast photomicrographs from life: a, Euplotes sp.; b, Notohymena sp.; $\boldsymbol{c}$, Pseudourostyla sp.; d, Tetmemena sp. (scale bar represents $20 \mu \mathrm{m})$.

river between Okhla village to the west and Gautam Budh Nagar to the east. Spread over 4 sq. $\mathrm{km}$, the vegetation in the areas around the barrage is mainly thorny scrub, grassland and a wetland that was formed as a result of the Okhla Barrage. The sediment in the wetland consists of organic debris and fine sand. There is extensive growth of water hyacinths as well.

Site II: Sanjay Lake $\left(28.6142^{\circ} \mathrm{N}, 77.3039^{\circ} \mathrm{E}\right)$ : This is an artificial lake developed by the Delhi Development Authority (DDA) in Trilokpuri, East Delhi. Its surface area is about $1 \mathrm{sq} . \mathrm{km}$ and it has extensive growth of water hyacinth. It is mainly fed by rainwater, but also receives inputs of sewage.

Site III: Raj Ghat $\left(28.6406^{\circ} \mathrm{N}, 77.2494^{\circ} \mathrm{E}\right)$ : This is a memorial to Mahatma Gandhi. A man-made pond is situated in the vicinity; it has a maximum depth of about $4 \mathrm{~m}$, an average depth of about $2 \mathrm{~m}$ and a surface area of about 0.01 sq. $\mathrm{km}$.

\section{Collection, isolation and cultivation of ciliates}

Water samples, each $1000 \mathrm{ml}$, were collected from all the sampling sites at a depth of approx. $1 \mathrm{~m}$ using widemouthed plastic bottles. Nytex nets of decreasing mesh sizes were used in succession to filter out large crustaceans, debris and other unwanted materials. Several liters of water samples were strained through a mesh of size $<50 \mu \mathrm{m}$ and the concentrate containing ciliates was transferred to large troughs in the laboratory. Mixed planktonic cultures were initially grown at room temperature with addition of fresh boiled cabbage pieces to promote the growth of bacteria which serve as the food organism. Such water samples were subjected to periodic microscopic examination for about 20 days. Identification of ciliates was carried out in vivo under bright field and phase contrast microscopy at $10 \times$ and $40 \times$ magnification. Genus-level identifications were made according to Berger $^{18}$. For each ciliate species, clonal cultures were established and maintained at $22^{\circ} \pm 1^{\circ} \mathrm{C}$ in Pringsheim's medium $^{19}$. Also, boiled cabbage was added to the medium.

\section{Determination of heavy metal toxicity}

Toxicity assays for heavy metals ( $\mathrm{Cd}, \mathrm{Cu}, \mathrm{Ni}, \mathrm{Pb}$ and $\mathrm{Zn}$ ) were carried out in order to determine the tolerance degree limits (i.e. $0 \%$ to $100 \%$ survivability) of each of the four ciliate species. Stock solutions $(1000 \mathrm{mg} / \mathrm{l})$ of $\mathrm{CuSO}_{4}, \mathrm{CdCl}_{2}, \mathrm{NiCl}_{2} \cdot 6 \mathrm{H}_{2} \mathrm{O}, \mathrm{Pb}\left(\mathrm{NO}_{3}\right)_{2}$ and $\mathrm{ZnCl}_{2}$ were prepared in Pringsheim's medium and verified analytically by Atomic Absorption Spectroscopy (AAS-6300 Shimadzu Corp. 00740, University Science Instrumentation Centre (USIC), Delhi). For each species, 20 ciliate cells from the clonal cultures were exposed to a range of concentrations $-\mathrm{Cu} \quad(0.1-2.0 \mathrm{mg} / \mathrm{l}), \quad \mathrm{Cd} \quad(1-10 \mathrm{mg} / \mathrm{l}), \quad \mathrm{Ni}$ (1-10 mg/l), Pb (1-40 mg/l) and Zn (20-280 mg/l). Each treatment was carried out in triplicate and was performed without adding fresh food to the medium. Appropriate control experiments (without heavy metal additions) with the same number of cells were performed simultaneously. The time period for the toxicity treatment was selected as $24 \mathrm{~h}$ to allow the cells to undergo 2-3 divisions in the presence of various heavy metals. After $24 \mathrm{~h}$, the cells were counted under a Magnüs stereoscopic microscope at 20-40× magnification to determine per cent survival and 
Table 1. The $24 \mathrm{~h} \mathrm{LC}_{50}$ mean values of four freshwater ciliates tested with heavy metals $(n=60)$

\begin{tabular}{lcccc}
\hline & \multicolumn{4}{c}{ Species } \\
\cline { 2 - 5 } & \multicolumn{5}{c}{$24 \mathrm{~h} \mathrm{LC}_{50}(\mathrm{mg} / \mathrm{l})(95 \%$ confidence limit $)$} \\
\cline { 2 - 5 } Metals & Euplotes sp. & Notohymena $\mathrm{sp}$. & Pseudourostyla $\mathrm{sp}$. & Tetmemena sp. \\
\hline $\mathrm{Cd}$ & $2.2(1.6-2.8)$ & $5.1(4.0-6.9)$ & $2.3(1.3-3.4)$ & $2.4(1.7-3.2)$ \\
$\mathrm{Cu}$ & $0.2(0.1-0.2)$ & $0.7(0.4-1.2)$ & $0.1(0.1-0.2)$ & $0.1(0.1-0.2)$ \\
$\mathrm{Ni}$ & $4.5(3.9-5.1)$ & $4.3(3.6-5.0)$ & $5.0(3.6-6.6)$ & $1.9(1.6-2.4)$ \\
$\mathrm{Pb}$ & $5.5(4.7-7.7)$ & $22.9(17.7-29.5)$ & $5.4(4.6-7.6)$ & $7.7(6.1-12.5)$ \\
$\mathrm{Zn}$ & $124.2(92.7-158.7)$ & $46.9(30.5-54.7)$ & $74.6(49.1-113.1)$ & $144.3(111.4-216.6)$ \\
\hline
\end{tabular}

Figures in brackets represent the range of $\mathrm{LC}_{50}$ values.

mortality rate under different concentrations of test solutions. Non-motile and missing cells were considered as dead; mean value of viable cells in triplicates was calculated $^{10,20,21}$. Per cent survival was determined as

Total cells - Dead cells/Total cells $\times 100$.

\section{Statistical analysis}

The $\mathrm{LC}_{50}$ values and $95 \%$ confidence limits were determined by the Probit method ${ }^{22,23}$. The significance of difference of $\mathrm{LC}_{50}$ among species was compared by multiple comparison T3 Dunnett test ${ }^{24}$. These analyses were performed using the program IBM SPSS Statistics 19.

\section{Results}

\section{Heavy metal toxicity}

Table 1 shows the $24 \mathrm{~h} \mathrm{LC}_{50}$ values and associated $95 \%$ confidence limits of the four ciliate species exposed to the heavy metals (copper, cadmium, nickel, lead and zinc). The order of toxicity to heavy metals is as follows:
Euplotes sp.:
$\mathrm{Cu}>\mathrm{Cd}>\mathrm{Ni}>\mathrm{Pb}>\mathrm{Zn}$;
Notohymena sp.:
$\mathrm{Cu}>\mathrm{Ni}>\mathrm{Cd}>\mathrm{Pb}>\mathrm{Zn}$;
Pseudourostyla sp.:
$\mathrm{Cu}>\mathrm{Cd}>\mathrm{Ni}>\mathrm{Pb}>\mathrm{Zn}$;
Tetmemena sp.:
$\mathrm{Cu}>\mathrm{Ni}>\mathrm{Cd}>\mathrm{Pb}>\mathrm{Zn}$.

Figures $2-6$ show the mean survival value $( \pm \mathrm{SD})$ of the cells to different concentrations of heavy metals. The relative sensitivity of the ciliates to each metal is as follows:

Cd: Euplotes sp. > Pseudourostyla sp. > Tetmemena sp. $>$ Notohymena sp.

$\mathrm{Cu}$ : Pseudourostyla sp. $>$ Tetmemena sp. $>$ Euplotes sp. > Notohymena sp.

Ni: Tetmemena sp. $>$ Notohymena sp. $>$ Euplotes

sp. > Pseudourostyla sp.

$\mathrm{Pb}$ : Pseudourostyla sp. $>$ Euplotes sp. $>$ Tetmemena sp. > Notohymena sp.

Zn: Notohymena sp. $>$ Pseudourostyla sp. $>$ Euplotes sp. > Tetmemena $\mathrm{sp}$.

\section{Statistical analysis}

Significant differences $(P<0.001)$ were observed in the $\mathrm{LC}_{50}$ mean values for the four ciliates to each heavy metal (Table 1). The relative sensitivity of these ciliates to each metal was also found to be significantly different as analysed by T3 Dunnett test (Table 2).

\section{Discussion}

Toxicity data collated from various studies show that different protists exhibit variable sensitivity to different heavy metals (Table 3). Heavy metals influence the survival of ciliates by affecting certain physiological and ecological processes such as reduction in food uptake, inhibition of growth and reduction in the rate of endocytosis as observed in Tetrahymena ${ }^{25,26}$. The present study also shows that copper is the most toxic heavy metal and zinc the least toxic in all the four studied species of ciliates. Earlier studies on Uronema sp., Drepanonomus revoluta and Euplotes sp. also illustrated that cellular toxicity of zinc is low ${ }^{9}$. Zinc is an essential metal which constitutes a catalytic and structural compound for many enzymes. A study conducted by Nilsson ${ }^{27}$ on $T$. pyriformis also concluded that this ciliates adapt quickly to excess amount of zinc. The toxicity of $\mathrm{Cu}$ may be more than $\mathrm{Zn}$ as suggested in in silico studies on Tetrahymena that zinc-binding proteome constitutes up to $9 \%$ of the total proteome, whereas $\mathrm{Cu}$-binding proteome constitutes only $0.07 \%$ of the entire proteome ${ }^{28}$.

Among the four ciliates, Notohymena sp. had the highest tolerance to three of the tested heavy metals (Table 2). The high tolerance in Notohymena sp. may be attributed to the presence of a large number of cytoplasmic granules within the cell. It has been demonstrated that in other protists such as the ciliate Tetrahymena, cytoplasmic granules play a major role in compartmentalization of metals, thereby increasing tolerance ${ }^{29,30}$. Exposure of ciliates to heavy metals also led to the formation of cytoplasmic vacuoles that contain electron-dense particles. The phenomenon of metal accumulation in granules and membrane-enclosed vesicles is widespread in numerous phyla 

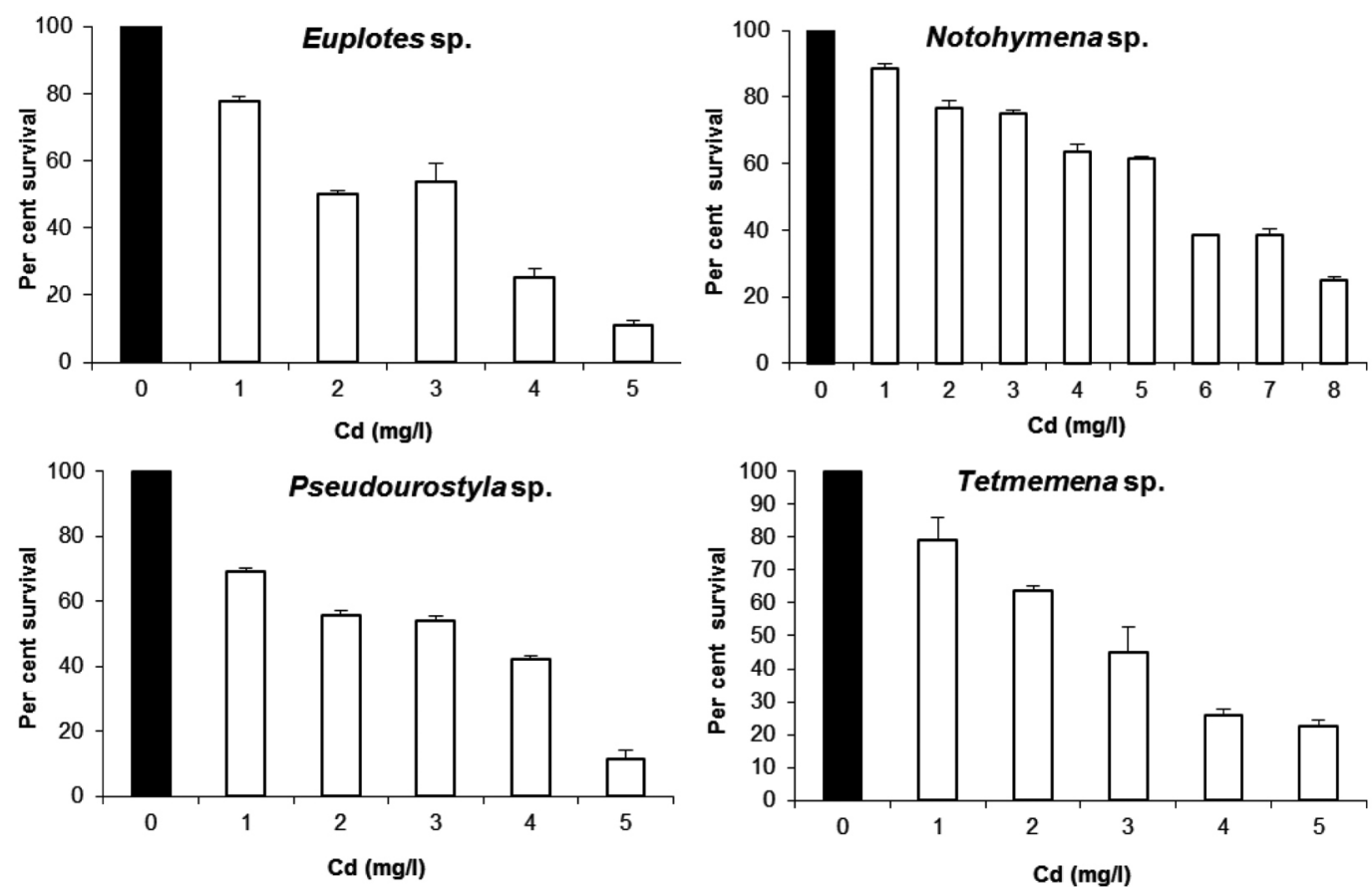

Figure 2. Mean survival values $( \pm \mathrm{SD})$ of the four freshwater ciliate species after $24 \mathrm{~h}$ exposure to cadmium.
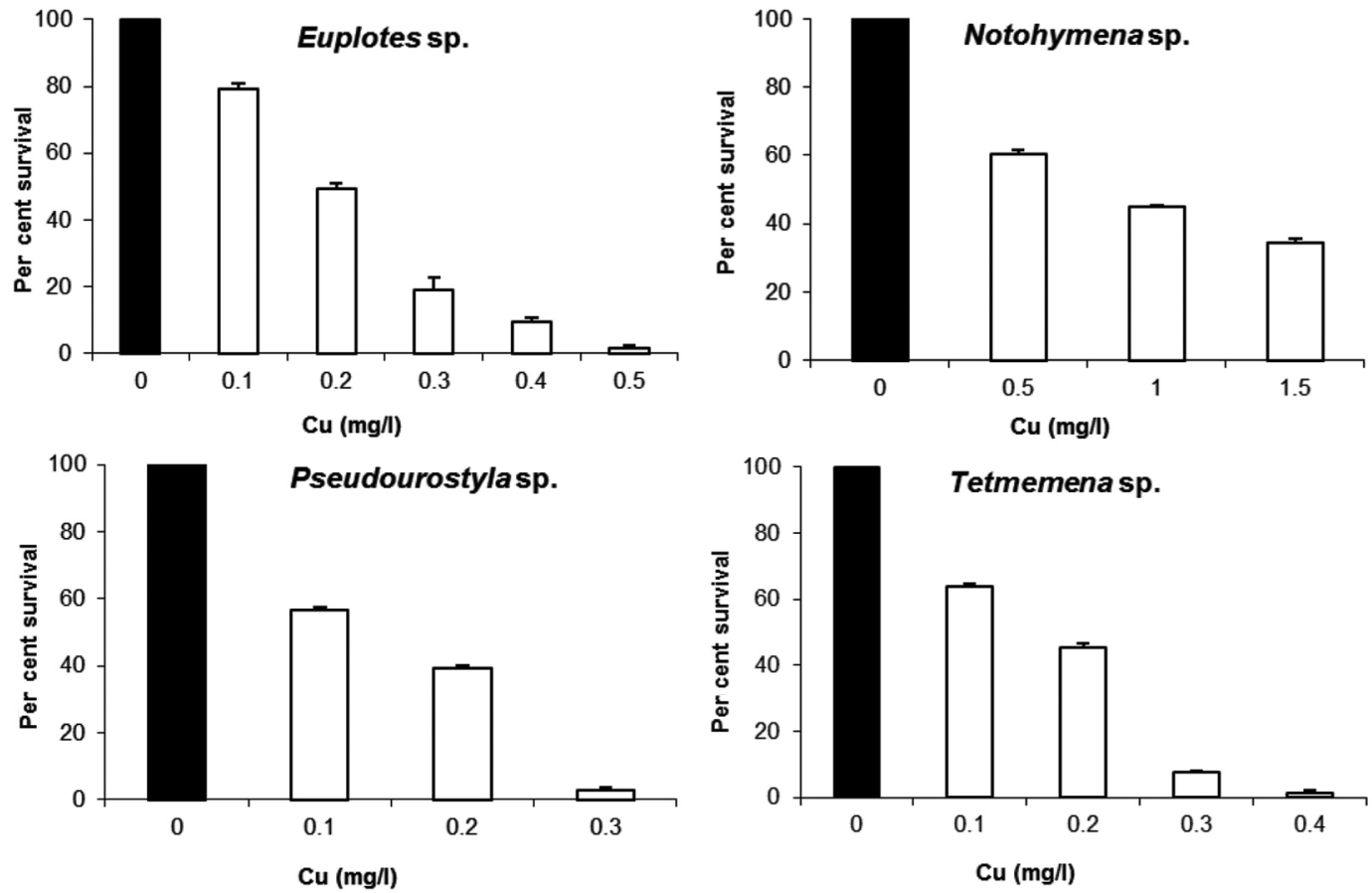

Figure 3. Mean survival values $( \pm \mathrm{SD})$ of the four freshwater ciliate species after 24 h exposure to copper.

from protozoa to mammals. Similar cytoplasmic electrondense accumulations have also been found in Stylonchia lemnae $^{31}$. It is possible that these cytoplasmic granules consist of complexes formed by metallic cations $\left(\mathrm{Cd}^{2+}\right.$, $\mathrm{Zn}^{2+}$, etc.) and metallothioneins (MTs) as revealed by the use of metal fluorophores for the first time in ciliates ${ }^{21}$.
The expression of MT genes increases in the presence of heavy metals, thus helping detoxification ${ }^{32-37}$. The high tolerance of ciliates to $\mathrm{Zn}$ may be explained by the fact that $\mathrm{Cd}-\mathrm{MT}$ can also be induced by $\mathrm{Zn}^{21,38}$. The order of bioaccumulation of metals in ciliates is $\mathrm{Zn}>\mathrm{Cd}>\mathrm{Cu}^{21}$. Higher bioaccumulation of zinc compared to cadmium 

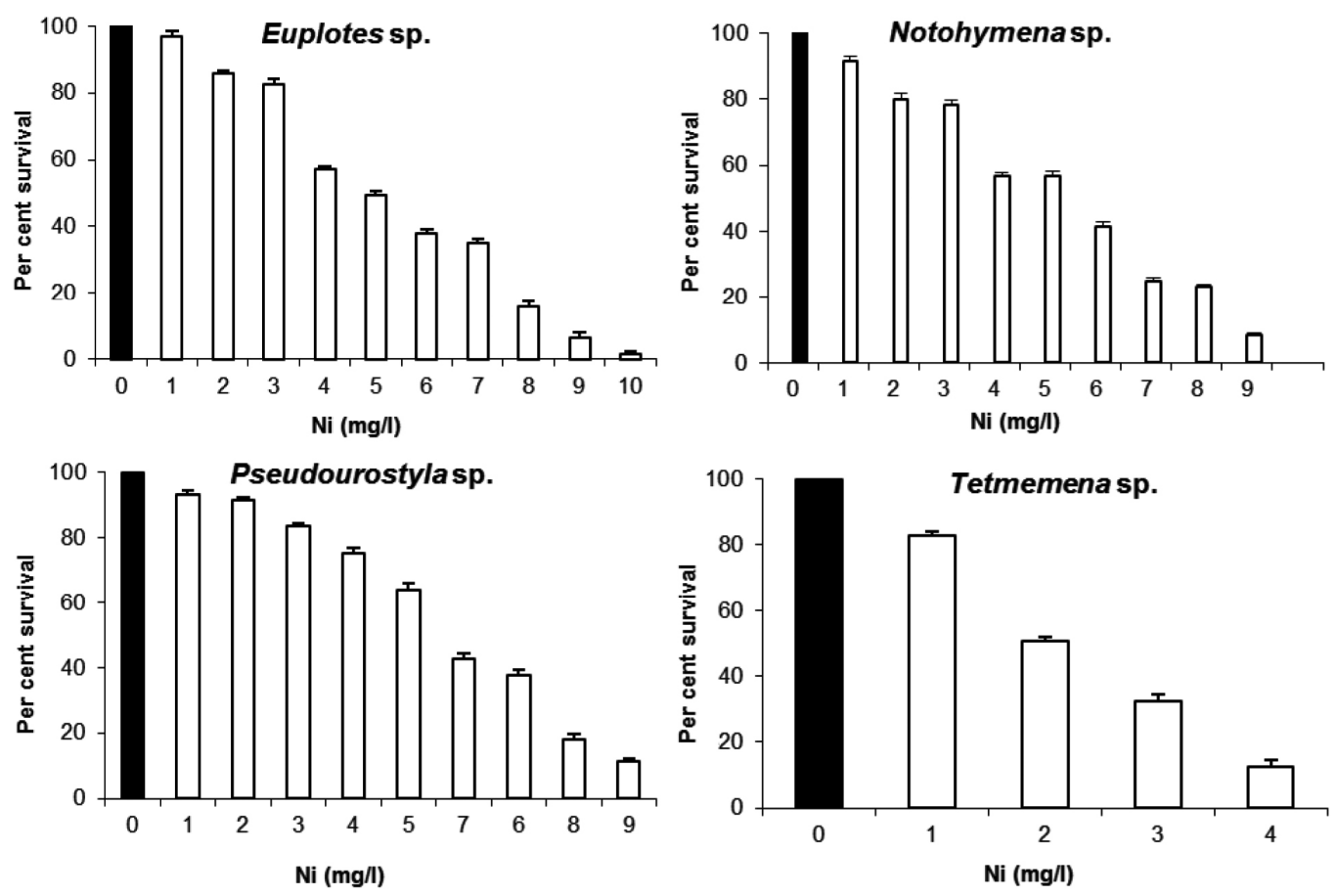

Figure 4. Mean survival values $( \pm \mathrm{SD})$ of the four freshwater ciliate species after $24 \mathrm{~h}$ exposure to nickel.
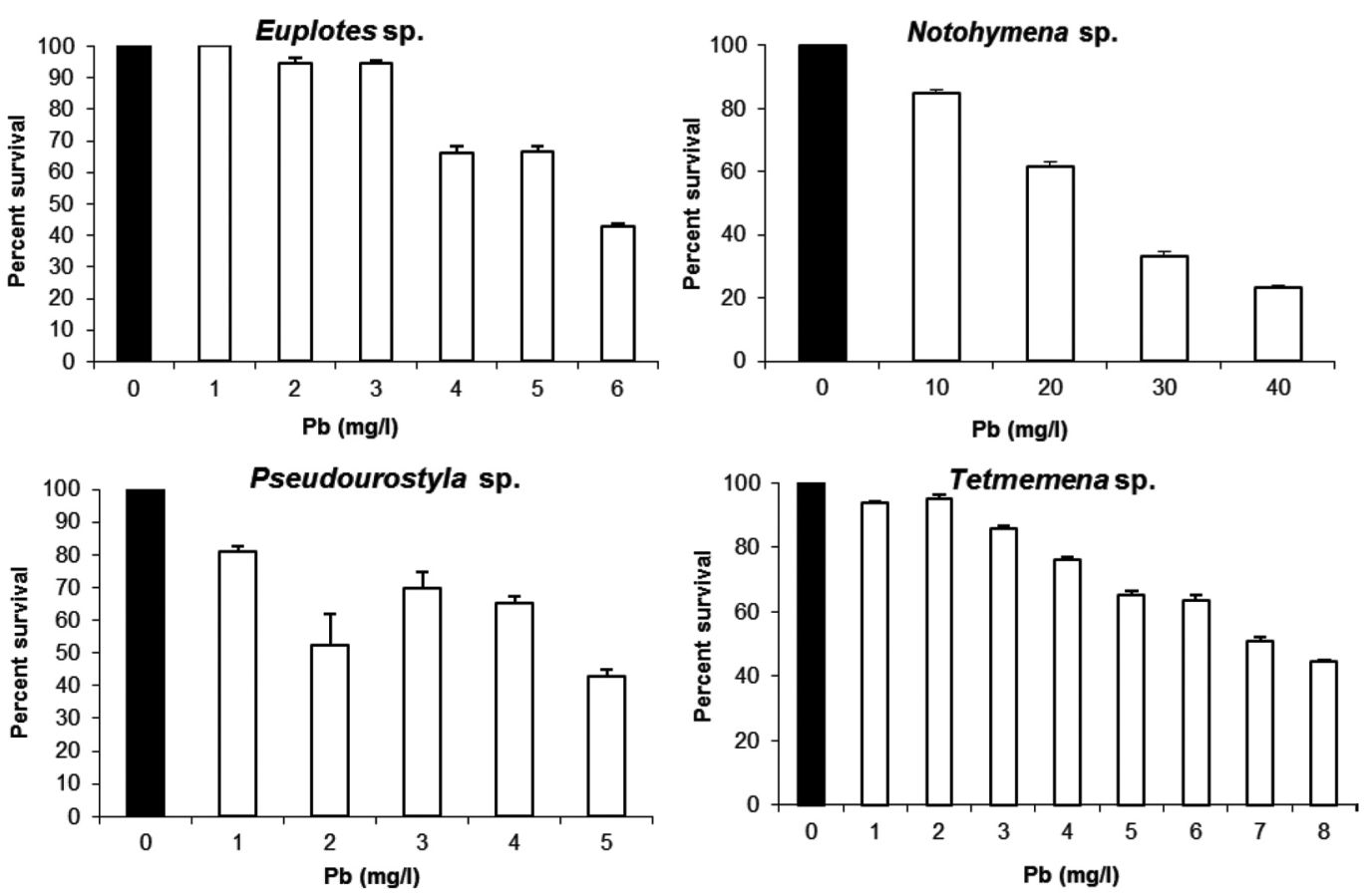

Figure 5. Mean survival values $( \pm S D)$ of the four freshwater ciliate species after 24 h exposure to lead.

and copper may also be attributed to low toxicity of the former compared to cadmium and copper. Other reported studies show that ciliates are more sensitive to $\mathrm{Cu}$ and its bioaccumulation seems to be less efficient than in other microorganisms, particularly microalgae such as Chlorella $^{21,39,40}$.
In the present study, variation in tolerance range to various metals in different genera was observed. The apparent difference in toxicity of any given metal might, however, be due to many factors, one of which could be the diversity of experimental conditions: certain factors such as $\mathrm{pH}$ and composition of the surrounding medium 


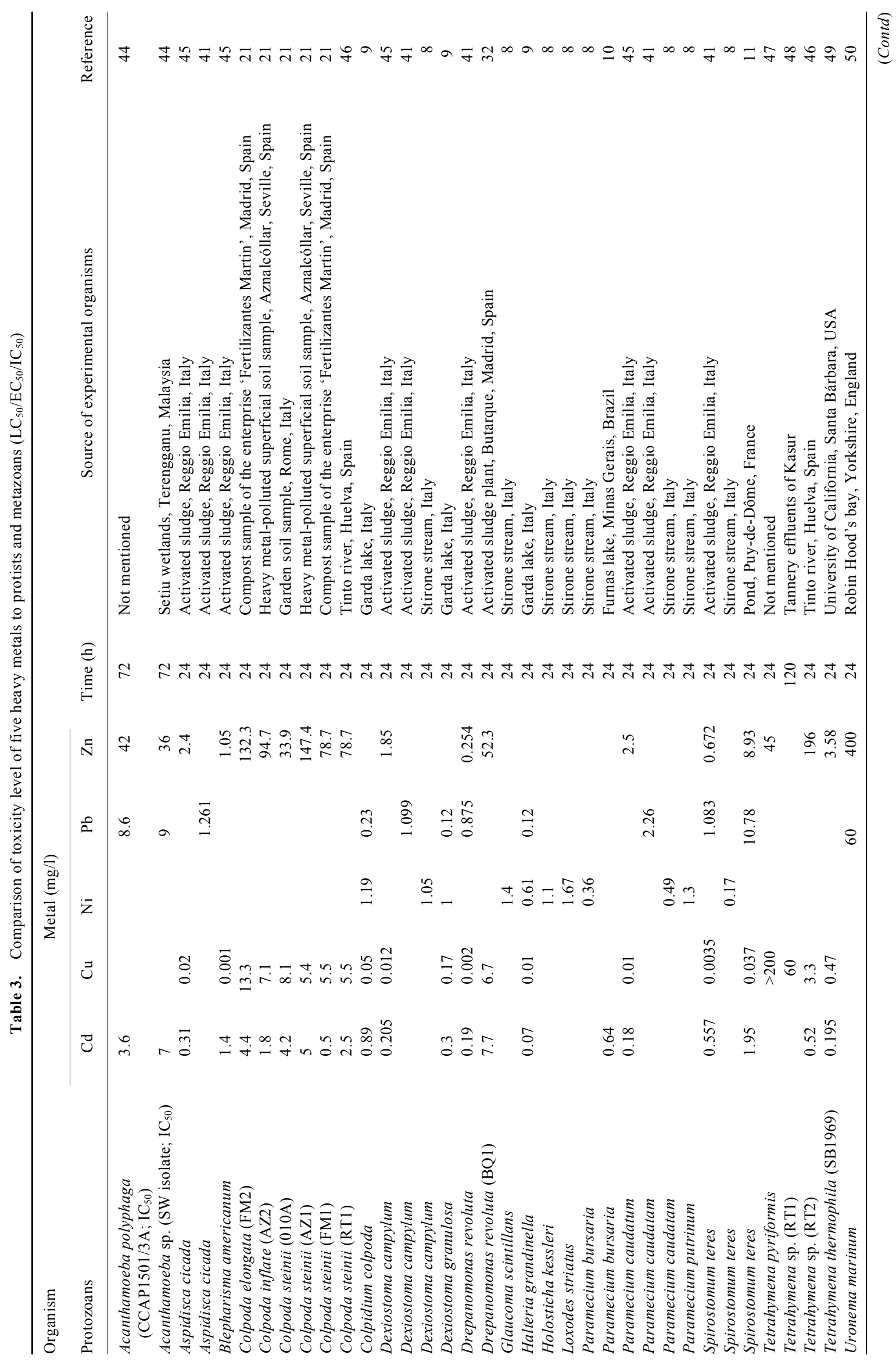




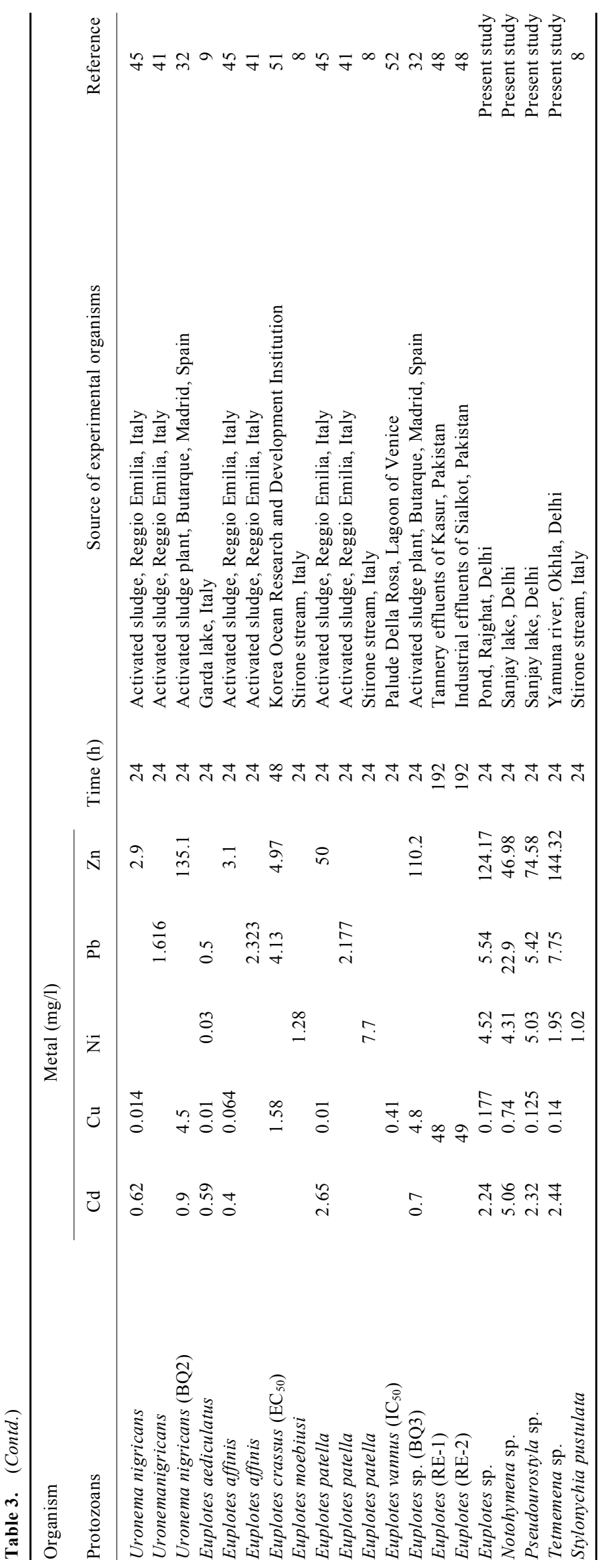


Table 2. Multiple comparisons of the mean $\mathrm{LC}_{50}$ values by T3 Dunnett test

\begin{tabular}{|c|c|c|c|c|c|c|c|}
\hline \multirow[b]{2}{*}{ Metal } & \multirow[b]{2}{*}{ Species } & \multirow[b]{2}{*}{$\mathrm{LC}_{50}(\mathrm{mg} / \mathrm{l})$} & \multirow[b]{2}{*}{ SD } & \multicolumn{4}{|c|}{$\begin{array}{l}\text { Significance of the difference between } \\
\text { mean } \mathrm{LC}_{50} \text { values }\end{array}$} \\
\hline & & & & $\mathrm{a}$ & $\mathrm{b}$ & $\mathrm{c}$ & d \\
\hline \multirow[t]{4}{*}{$\mathrm{Cd}$} & $\mathrm{a}$ & 2.44 & 0.54 & - & ns & $*$ & ns \\
\hline & $\mathrm{b}$ & 2.32 & 0.66 & ns & - & * & ns \\
\hline & $\mathrm{c}$ & 5.06 & 0.45 & $*$ & $*$ & - & $* *$ \\
\hline & d & 2.24 & 0.43 & ns & ns & $* *$ & - \\
\hline \multirow[t]{4}{*}{$\mathrm{Cu}$} & a & 0.14 & 0.01 & - & ns & $*$ & ns \\
\hline & $\mathrm{b}$ & 0.12 & 0.005 & ns & - & * & ns \\
\hline & $\mathrm{c}$ & 0.74 & 0.12 & $*$ & $*$ & - & $*$ \\
\hline & d & 0.18 & 0.02 & ns & ns & $*$ & - \\
\hline \multirow[t]{4}{*}{$\mathrm{Ni}$} & $\mathrm{a}$ & 1.95 & 0.26 & - & $* *$ & $*$ & $* *$ \\
\hline & $\mathrm{b}$ & 5.03 & 0.37 & $* *$ & - & ns & ns \\
\hline & $\mathrm{c}$ & 4.31 & 0.51 & $*$ & ns & - & ns \\
\hline & d & 4.52 & 0.35 & $* *$ & ns & ns & - \\
\hline \multirow[t]{4}{*}{$\mathrm{Pb}$} & $\mathrm{a}$ & 7.75 & 0.56 & - & $\mathrm{ns}$ & $*$ & ns \\
\hline & $\mathrm{b}$ & 5.42 & 2.82 & ns & - & $* *$ & ns \\
\hline & c & 22.97 & 2.97 & $*$ & $* *$ & - & $*$ \\
\hline & d & 5.54 & 0.80 & ns & ns & * & - \\
\hline \multirow[t]{4}{*}{$\mathrm{Zn}$} & $\mathrm{a}$ & 144.32 & 1 & - & * & * & $*$ \\
\hline & $\mathrm{b}$ & 74.58 & 1 & $*$ & - & * & $*$ \\
\hline & $\mathrm{c}$ & 46.98 & 0.5 & $*$ & * & - & $*$ \\
\hline & d & 124.17 & 1.01 & $*$ & $*$ & $*$ & - \\
\hline
\end{tabular}

$* P<0.05 ; * * P<0.01 ; \mathrm{ns}$, Nonsignificant.
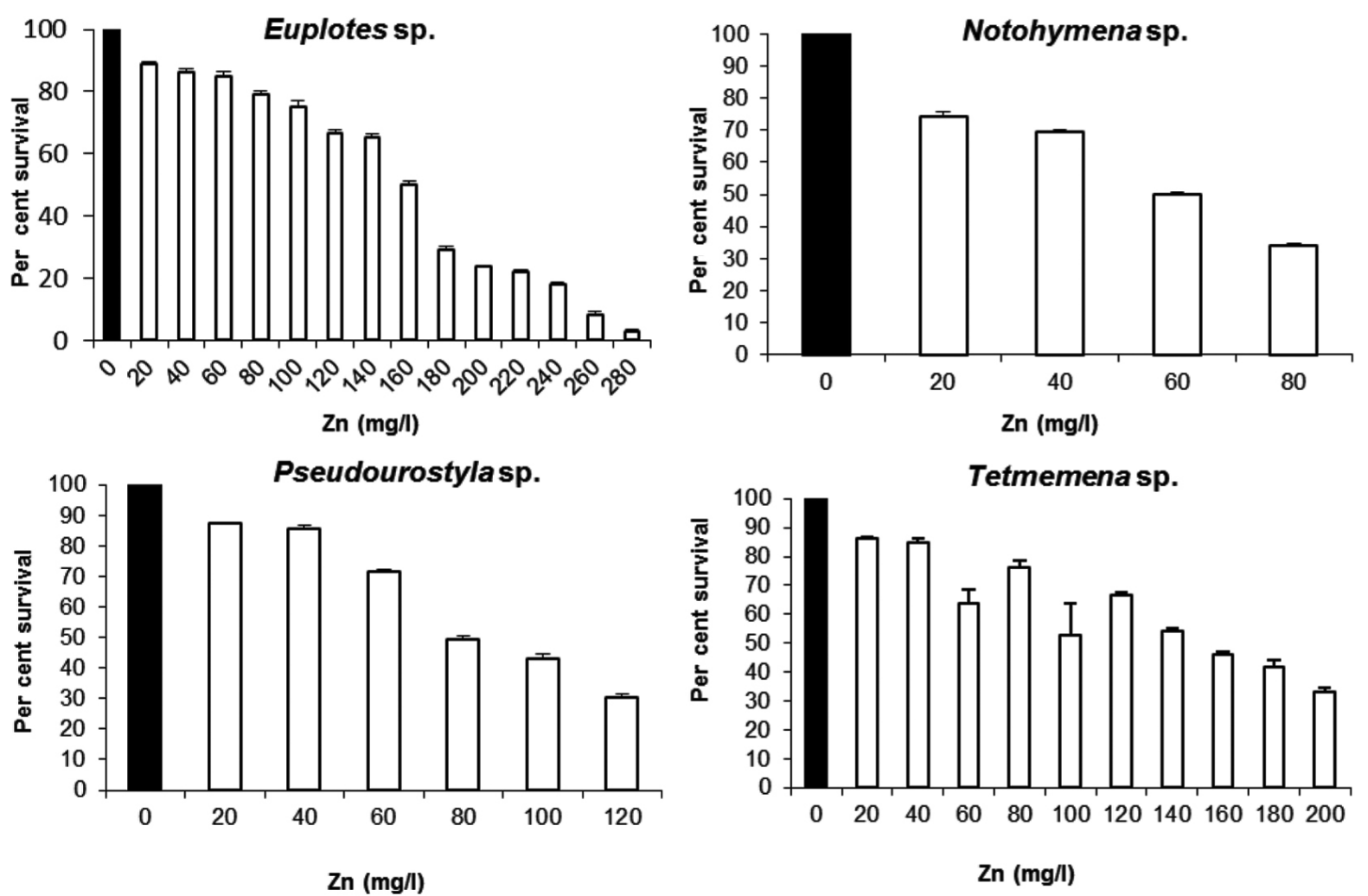

Figure 6. Mean survival values $( \pm \mathrm{SD})$ of the four freshwater ciliate species after 24 h exposure to zinc. 
are known to influence the bioavailability of metallic ions and therefore their potential toxicity ${ }^{16}$. Another important factor is the cell concentration used during treatment. Some tests have used $8-12$ cells per bioassay, whereas in others $10^{3}-10^{5}$ cells $/ \mathrm{ml}$ have been used ${ }^{16,41,42}$. Cell concentration modifies metallic bioavailability and thereby changes the cytotoxicity.

The results reported herein showed the potential utility of ciliates in ecotoxicological studies because of their varied sensitivity to different heavy metals. Many studies on the dynamics of protozoan communities in heavy metal-polluted waters, activated sludge and wastewater treatment plants have shown the potentiality of using ciliates in ecotoxicological bioassays ${ }^{9,21,43}$. Also, this approach is economical and simple, and may provide a benchmark for monitoring the intensity and potency of ecological damage caused by anthropogenic activities. Future work will focus on the mechanism of heavy metal action on ciliates and to elucidate the cellular and molecular mechanisms that ciliates adopt to combat heavy metal stress. The possibility of using ciliates as whole-cell biosensors to assess heavy metal pollution in the freshwater bodies of Delhi region appears an achievable goal.

Conflict of interest. The authors declare that there is no conflict of interest regarding the publication of this manuscript.

1. Malik, D., Singh, S., Thakur, J., Singh, R. K., Kaur, A. and Nijhawan, S., Heavy metal pollution of the Yamuna River: an introspection. Int. J. Curr. Microbiol. Appl. Sci., 2014, 3, 856863.

2. Bhattacharya, A. K., Mandal, S. N. and Das, S. K., Heavy metals accumulation in water, sediment and tissues of different edible fishes in upper stretch of Gangetic West Bengal. Trends Appl. Sci. Res., 2008, 3, 61-68.

3. Karbassi, A. R., Bayati, I. and Moattar, F., Origin and chemical partitioning of heavy metals in riverbed sediments. Int. J. Environ. Sci. Technol., 2006, 3, 35-42.

4. Sirohi, S., Sirohi, S. P. S. and Tyagi, P. K., Impact of industrial effluents on the water quality of Kali River in different locations of Meerut, India. J. Eng. Technol. Res, 2014, 6, 43-47.

5. Cui, B., Zhang, Q., Zhang, K., Liu, X. and Zhang, H., Analyzing trophic transfer of heavy metals for food webs in the newlyformed wetlands of the Yellow River Delta, China. Environ. Pollut., 2011, 159, 1297-1306.

6. Ghorade, I. B., Lamture, S. V. and Patil, S. S., Assessment of heavy metal content in Godavari river water. Int. J. Res. Appl. Nat. Soc. Sci., 2014, 2, 23-26.

7. Lovley, D. R., Environmental Microbe-Metal Interactions, ASM Press, Washington, DC, USA, 2000.

8. Madoni, P., The acute toxicity of nickel to freshwater ciliates. Environ. Pollut., 2000, 109, 53-59.

9. Madoni, P. and Romeo, M. G., Acute toxicity of heavy metals towards freshwater ciliated protists. Environ. Pollut., 2006, 141, $1-7$.

10. Wanick, R. C., da Paiva, T. S., de Carvalho, C. N. and da SilvaNeto, I. D., Acute toxicity of cadmium to freshwater ciliate Paramecium bursaria. Biociências (Porto Alegre), 2008, 16, 104-109.

11. Twagilimana, L., Bohatier, J., Groliere, C. A., Bonnemoy, F. and Sargos, D., A new low-cost microbiotest with the protozoan Spirostomum teres: culture conditions and assessment of sensiti- vity of the ciliate to 14 pure chemicals. Ecotoxicol. Environ. Saf., 1998, 41, 231-244.

12. Gutiérrez, J. C., Amaro, F. and Martín-González, A., From heavy metal-binder to biosensor: ciliate metallothionein discussed. Bioessays, 2009, 31, 805-816.

13. Rao, A. N. and Hussain, M. M., Ecophysiological and cytopathological impact of deflin insecticide (Bacillus thuringiensis) to an unicellular ciliate protozoan, Euplotes patella. Res. J. Recent Sci., 2012, 1, 64-67.

14. Turkewitz, A. P., Orias, E. and Kapler, G., Functional genomics: the coming of age for Tetrahymena thermophila. Trends Genet., 2002, 18, 35-40.

15. Gilron, D. L. and Lynn, D. H., Ciliated protozoa as test organisms in toxicity assessments. In Microscale Testing in Aquatic Toxicology: Advances, Techniques and Practice (eds Wells, P. G. et al.), CRC Press, Boca Raton, FL, USA, 1998, pp. 323-336.

16. Gutiérrez, J. C., Martín-González, A., Díaz, S. and Ortega, R., Ciliates as a potential source of cellular and molecular biomarkers/biosensors for heavy metal pollution. Eur. J. Protistol., 2003, 39, 461-467.

17. Payne, R. J., Seven reasons why protists make useful bioindicators. Acta Protozool., 2013, 52, 105-113.

18. Berger, H., Monograph of the oxytrichidae (Ciliophora, Hypotrichia). In Monographie Biologicae, Kluwer, Dordrecht, The Netherlands, 1999.

19. Chapman-Andresen, C., Pinocytosis of inorganic salts by Amoeba proteus (Chaos diffluens). C. R. Trav. Lab. Carlsberg Chim., 1958, 31, 77-92.

20. Dias, N. and Lima, N., A comparative study using a fluorescencebased and a direct count assay to determine cytotoxicity in Tetrahymena pyriformis. Res Microbiol., 2002, 153, 313-322.

21. Díaz, S., Martín-González, A. and Gutiérrez, C. J., Evaluation of heavy metal acute toxicity and bioaccumulation in soil ciliated protozoa. Environ. Int., 2006, 32, 711-717.

22. Finney, D. J., Probit Analysis, Cambridge University Press, Cambridge, 1971, 3rd edn.

23. Sokal, R. R. and Rohlf, F. J., Biometry: the Principles and Practice of Statistics in Biological Research, W.H. Freeman and Company, New York, USA, 1995, 3rd edn.

24. Dunnett, C. W., A multiple comparison procedure for comparing several treatments with a control. J. Am. Stat. Assoc., 1955, 50, 1096-1121.

25. Nilsson, J. R., Phagotrophy in Tetrahymena. In Biochemistry and Physiology of Protozoa (eds Levandowsky, M. and Hunter, S. H.), Academic Press, New York, 1979, pp. 339-379.

26. Nilsson, J. R., Effects of copper on phagocytosis in Tetrahymena. Protoplasma, 1981, 109, 359-370.

27. Nilsson, J. R., How cytotoxic is zinc? A study on effects of zinc on cell proliferation, endocytosis and fine structure of the ciliate Tetrahymena. Acta Protozool., 2003, 42, 19-29.

28. Chasapis, C. T., Andreini, C., Georgiopolou, A. K., Stefanidou, M. E. and Vlamis-Gardikas, A., Identification of the zinc, copper and cadmium metalloproteome of the protozoon Tetrahymena thermophila by systematic bioinformatics. Arch. Microbiol., 2017, doi:10.1007/s00203-017-1385-y.

29. Dunlop, S. and Chapman, G., Detoxification of zinc and cadmium by freshwater protozoan Tetrahymena pyriformis. II. Growth experiments and ultrastructural studies on sequestration of heavy metals. Environ. Res., 1981, 24, 264-274.

30. Krawczynska, W., Pivovarova, N. N. and Sobota, A., Effects of cadmium on growth, ultrastructure and content of chemical elements in Tetrahymena pyriformis and Acanthamoeba castellanii. Acta Protozool., 1989, 28, 245-252.

31. Makhija, S., Gupta, R., Toteja, R., Abraham, J. S. and Sripoorna, S., Cadmium induced ultrastructural changes in the ciliate, Stylonychia mytilus (Ciliophora, Hypotrichida). J. Cell Tissue Res., 2015, 15, 5151-5157. 


\section{RESEARCH ARTICLES}

32. Martín-González, A., Díaz, S., Borniquel, S., Gallego, A. and Gutiérrez, J. C., Cytotoxicity and bioaccumulation of heavy metals by ciliated protozoa isolated from urban wastewater treatment plants. Res. Microbiol., 2006, 157, 108-118.

33. Boldrin, F., Santovito, G., Irato, P. and Piccinni, E., Metal interaction and regulation of Tetrahymena pigmentosa metallothionein genes. Protist, 2002, 153, 283-291.

34. Fu, C. and Miao, W., Cloning and characterization of a new multistress inducible metallothionein gene in Tetrahymena pyriformis. Protist, 2006, 157, 193-203.

35. Guirola, M., Pérez-Rafael, S., Capdevila, M., Palacios, Ò. and Atrian, S., Metal dealing at the origin of the chordata phylum: the metallothionein system and metal overload response in Amphioxus. PLoS ONE, 2012, 7, e43299.

36. Gutiérrez, J. C., Amaro, F. and Martín-González, A., Heavy metal whole biosensors using eukaryotic microorganisms: an updated critical review. Front. Microbiol., 2015, 6, 1-8.

37. Torreggiani, A., Chatgilialoglu, C., Ferreri, C., Melchiorre, M., Atrian, S. and Capdevila, M., Non-enzymatic modifications in metallothioneins connected to lipid membrane damages: structural and biomimetic studies under reductive radical stress. J. Proteomics, 2013, 92, 204-215.

38. Klaassen, C. D., Liu, J. and Choudhuri, S., Metallothionein: an intracellular protein to protect against cadmium toxicity. Annu. Rev. Pharmacol. Toxicol., 1999, 39, 267-294.

39. Brady, D., Letebele, B., Duncan, J. R. and Rose, P. D., Bioaccumulation of metals by Scenedesmus, Selenastrum and Chlorella algae. Water $S A, 1994,20,213-218$.

40. Vymazal, J., Toxicity and accumulation of cadmium with respect to algae and cyanobacteria: a review. Environ. Toxicol., 1987, 2, 387-415.

41. Madoni, P., Davoli, D. and Gorbi, G., Acute toxicity of lead, chromium, and other heavy metals to ciliates from activated sludge plants. Bull. Environ. Contam. Toxicol., 1994, 53, 420 425 .

42. Martín-González, A., Benítez, L., Soto, T., Rodríguez de Lecea, J. and Gutiérrez, J. C., A rapid bioassay to detect mycotoxins using a melanin precursor overproducer mutant of the ciliate Tetrahymena thermophila. Cell Biol. Int., 1997, 21, 213-221.

43. Nicolau, A., Martins, M. J., Mota, M. and Lima, N., Effect of copper in the protistan community of activated sludge. Chemosphere, 2005, 58, 605-614.

44. Amin, N. M., Techniques for assessment of heavy metal toxicity using Acanthamoeba sp., a small, naked and free-living amoeba. In The Functioning of Ecosystems (eds Ali, M.), InTech, 2012, pp. 199-212.
45. Madoni, P., Esteban, G. and Gorbi, G., Acute toxicity of cadmium, copper, mercury, and zinc to ciliates from activated sludge plants. Bull. Environ. Contam. Toxicol., 1992, 49, 900-905.

46. Rico, D., Martín-González, A., Díaz, S., de Lucas, P. and Gutiérrez, J. C., Heavy metals generate reactive oxygen species in terrestrial and aquatic ciliated protozoa. Comp. Biochem. PhysiolPart C, 2009, 149, 90-96.

47. Nicolau, A., Mota, M. and Lima, N., Physiological responses of Tetrahymena pyriformis to copper, zinc, cycloheximide and Triton X-100. FEMS Microbiol. Ecol., 1999, 30, 209-216.

48. Chaudhry, R. and Shakoori, A. R., Characterization of copper resistant ciliates: potential candidates for consortia of organisms used in bioremediation of wastewater. Afr. J. Biotechnol., 2011, 10, 9101-9113.

49. Gallego, A., Martín-González, A., Ortega, R. and Gutiérrez, J. C., Flow cytometry assessment of cytotoxicity and reactive oxygen species generation by single and binary mixtures of cadmium, zinc and copper on populations of the ciliated protozoan Tetrahymena thermophila. Chemosphere, 2007, 68, 647-661.

50. Parker, J. G., Toxic effects of heavy metals upon cultures of Uronema marinum (Ciliophora: Uronematidae). Mar. Biol., 1979, 54, 17-24.

51. Kim, S. H., Jung, M. Y. and Lee, Y. M., Effect of heavy metals on the antioxidant enzymes in the marine ciliate Euplotes crassus. Toxicol. Environ. Health Sci., 2011, 3, 213-219.

52. Coppellotti, O., Sensitivity to copper in a ciliate as a possible component of biological monitoring in the Lagoon of Venice. Arch. Environ. Contam. Toxicol., 1998, 35, 417-425.

ACKNOWLEDGEMENTS. We thank the Principal, Acharya Narendra Dev College, University of Delhi for providing the necessary facilities; Prof. G. R. Sapra (formerly at Department of Zoology, New Delhi) for his guidance and support, and University Grants Commission (F. No. 41-15/2012 (SR)) and the Department of Science and Technology (SERB/F/1891/2012-13), New Delhi for funds. We also thank anonymous reviewers for their critical reviews and suggestions, that helped improve the manuscript.

Received 24 December 2016; revised accepted 24 June 2017

doi: $10.18520 / \mathrm{cs} / \mathrm{v} 113 / \mathrm{i} 11 / 2141-2150$ 